\title{
乾燥, 給湿および空気調和用の新しい湿り空気線図*
}

（第 4 報） 乾燥機に対する線図の応用

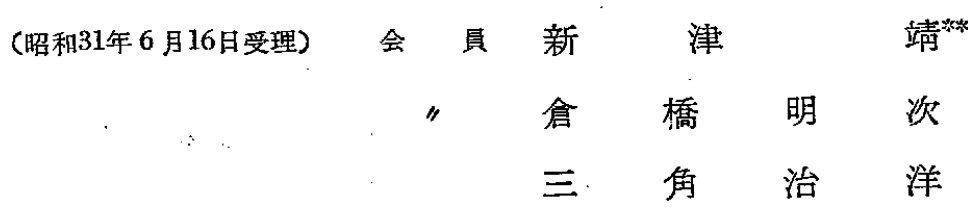

\section{研 究目的}

乾燥機内は一般に空気調和における状熊变化より遥かに高温なので, 著者は $0 \sim 200^{\circ} \mathrm{C}$ の範囲の乾燥機厈湿り空 気 $i 一 x$ 線図を作った。(第 1 報参照) よってこの乾燥機内空気状態の变化を線图上に追跡し, 実際に利用されて いる諸種の乾燥方式の乾燥過程についてこれを線図表示しようとする.

\section{䂠 究 結 果}

実際の乾燥過程は非常に複雑な状態变化であるが, 近似的に定常温度線と周辺尺度線とを用いることによって， 乾煤機内空気状態变化を線図表示することができることを明らがし, 連続式乾燥, 乾燥室による乾燥への応用を 論じ，続いて燃焼ガス利用の乾懆にるi一x 線図を適用できることを示した。

\section{1. 乾燥譏內空気状態変化の線図表示}

一般に物質の乾燥は水蒸気で䳌和されていない空気が その表面と接触することによって行われ，乾燥室気と湿 った物質との温度および湿度すなわち蒸気圧差が乾橾の 原動力であることは論をなたない。

いま乾燥機内の空気状態変化を考兄るに当り，新たに 次の記号を用いる。

$Q=$ 単位時間当りの消費熱量 $\mathrm{kcal} / \mathrm{h}$

$D=$ 単位時間についての機内通過乾燥物重量 $\mathrm{kg} / \mathrm{h}$

$C D=$ 乾懆物比熱 $\mathrm{kcal} / \mathrm{kg}{ }^{\circ} \mathrm{C}$

$t_{D}=$ 乾燥物温度 ${ }^{\circ} \mathrm{C}$

$Q_{l}=$ 乾燥機からの損失熱量 $\mathrm{kcal} / \mathrm{h}$

いま接尾符号 1 を乾燥前，2を乾燥後の状熊を示する のとすると, 乾燥前後の熱量関係式として次式が成り立 ๖.

$$
\begin{aligned}
Q+G_{a} i_{1}+D_{1} c_{D_{1}} t_{D_{1}}=G_{a} i_{2}+D_{2} c_{D 2} t_{D 2} \\
+G_{a}\left(x_{2}-x_{1}\right) r_{0}+Q_{l} \ldots \ldots \ldots \ldots \ldots \ldots
\end{aligned}
$$

単位時間当りの蒸登水分量 $W \mathrm{~kg} / \mathrm{h}$ は

$W=D_{1}-D_{2}$

よって蒸発水量 $1 \mathrm{~kg}$ について消費される熱量を $q$

$\mathrm{kcal} / \mathrm{kg}$ とすると

$$
q=\frac{Q}{W}
$$

また蒸発水量 $1 \mathrm{~kg}$ について必要な空気量を $l \mathbf{~ k g} / \mathbf{k g}$ とすると

$$
l=\frac{G_{a}}{W}=\frac{G_{a}}{G_{a}\left(x_{2}-x_{1}\right)}=\frac{1}{x_{2}-x_{1}}
$$

な拈

$$
D_{1} c_{D_{1}}=D_{2} c_{D_{2}}+W
$$

これらの関係式から次式が得られる。

$$
\begin{aligned}
& \frac{i_{2}-i_{1}}{x_{2}-x_{1}}=q+q_{0}-r_{0} \\
& \text { ここに } \\
& q_{0}=t_{D_{1}}-\left(\frac{D_{1}}{W}-1\right) c D_{2}\left(t_{D_{2}}-t_{D_{1}}\right)-\frac{Q_{l}}{W}
\end{aligned}
$$

この（93）式からわかるように, 乾燥機に扑ける乾燥 前後の空気状態を与えると, 乾燥に必要な熱量消費量を 求めることがでさる。

しかして $i_{2}-i_{1} / x_{2}-x_{1}=\Delta i / \Delta x$ の值は湿り空気 $i-x$ 線図の周辺尺度によって読みとられる.すなわら乾燥機 に入る宾気の状態点 $\left(i_{1}, x_{1}\right)$ と乾燥機を出た後の状態点 $\left(i_{2}, x_{2}\right)$ とを直線で結び，極 0 からこの線に平行に引き， 周辺尺度との交点の $\Delta i / \Delta x$ の值から $\left(q+q_{0}-r_{0}\right)$ が求 まる・な持 $q_{0}$ を(94) 式から算出すれば，蒸発水量

* New Psychrometric Charts of the Use of Drying, Humidifying and Air Conditioning. Part 4: Application to Drying Apparatus.

*\% Y. Niitsu, M. Kurahashi, Member. M. Misumi, 大阪大学工学部 
$1 \mathrm{~kg}$ 当りの消費等量 $q$ がわかる.

次に乾煤物の表面がその温度 $t_{D}$ の飽和湿り空気で覆 われている之考えられる場合には，乾燥空気 $(t, x)$ と の閒の熱交換量 $Q \mathrm{kcal} / \mathrm{h}$ は

$$
Q=\alpha F\left(t-t_{D}\right)
$$

でり，一方乾燥物からの蒸発水量 $W \mathrm{~kg} / \mathrm{h}$ は

$$
W=\beta F\left(x_{D}-x\right)
$$

したがって蒸発熱量は $t_{D}{ }^{\circ} \mathrm{C}$ の蒸発潜熱を $r$ とすると $Q^{\prime}=W r$

しかして乾㤾物表面が空気だけから熱をうけ，他の熱 源から熱の供給をうけないときには

$$
Q=Q^{\prime}
$$

であり，定常状態に括いては

$$
\frac{\alpha}{\beta}=\frac{x_{D}-x}{t-t_{D}} r
$$

の関保が成立し，定常温度線 $て$ によって結びつけられ る.なお一般に $Q \neq Q^{\prime}$ の時には乾燥物温度々乾燥空気 状態は相互に变化するが，ある乾燥物温度に相当する定 常温度線てはそのときどきに応じて仮想的に考えても 差し支えない。

次に穴気流と接している乾燥物表面上に流れの方向に 単位巾 $d s$ の微小長さをとって考えると,この表面を流 れる空気のエンタルピと絕対湿度増加の割合は

$$
d i / d x=t_{D}-r_{0}
$$

で示される・したがって右辺の值が一定の範囲では $d i / d x$ 江階差商 $\Delta i / \Delta x=i_{2}-i_{1} / x_{2}-x_{1}$ で置き換元られ る.すなわち乾噪物表面温度 $t \dot{D}$ 上を流れる室気の状態 变化は $\Delta i / \Delta x$ の周辺尺度を利用して $i-x$ 線図上に变化 の方向を知ることができる。

このように乾焑機内穴気状態变化は定常温度線および $\Delta i / \Delta x$ の方向線を適当に組合せて使用することによっ て，ある程度線図上に状熊の解析が可能である。

しかしてこれまでは主に乾燥物表面の湿り宾気がその 温度の飽和湿り空気であると考えて論じてきたが，これ は乾燥速度が一定である恒率乾燥期には十分当てはまる 現象である・しかし乾燥終末過程の減率期間では必ずし す乾燥物表面は的和湿り空気で覆われているとは断定で きない．しかし減率期に対しても脱水量から乾燥後の空 気の紦対湿度を算出し，この $x_{2}$ 線を定常温度線の代り に用いれば $\Delta i / \Delta x$ 線と組合せて解析できる。

一般に倝煤現象は極めて複雑なるのであるが，繊維類 などの乾燥はその韯維組織によって粘土，木材などに比 べて恒率乾燥期間が減率乾燥期間よりも比較的長い性質 をむつので, 乾燥物表面の湿り空気は常に飽和している
として，線図上に解析することはかなり高い近似度をる こて許されるであろう。

\section{2. 連続式乾燥機と線図}

この型の乾燥機に扔いてはたとえば織布などの乾燥物 は連続的に供給され，軲燥空気によって乾燥される。

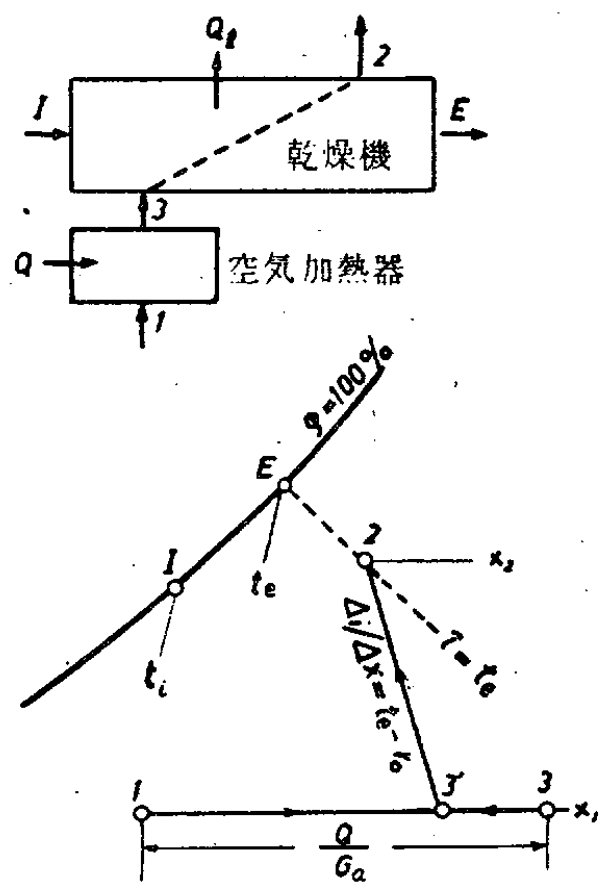

(第 24、园)

第 24四はこのような装置の概略を示したるのである。 すなわら状態 $1\left(x_{1}, t_{1}, i_{1}\right)$ の空気が空気加熱器により 熱量 $Q \mathrm{kcal} / \mathrm{h}$ を得て, 状態 3 の乾燥空気となって乾 燥室に入る．室内で熱交換を行うととむに乾燥物からの 蒸発水分を吸収して增湿され，状態 $2\left(x_{2}, t_{2}, i_{2}\right)$ の空気 となって乾燥機外飞排出される。一方乾燥物ははじめ $I$ 点 $\left(t_{i}, \varphi=100\right)$ で乾燥機内に送り込をれ, $E$ 点 $\left(t_{e}, \varphi\right.$ $=100 ）$ の状態となって出る．この場合の定常状態にお ける熱収支は次式によって与えられる。

$$
\begin{array}{r}
G_{a}\left(i_{1}+x_{1} r_{0}\right)+(D-W) c_{D} t_{i}+W t_{i}+Q \\
=G_{a}\left(i_{2}+x_{2} r_{0}\right)+(D-W) c_{D} t_{e}+Q_{t}
\end{array}
$$

蒸発水量 $W \mathrm{~kg} / \mathrm{h}$ は

$$
\begin{gathered}
W=G_{a}\left(x_{2}-x_{1}\right) \\
\therefore l=\frac{G_{a}}{W}=\frac{1}{x_{2}-x_{1}}
\end{gathered}
$$

また上式の関係から

$$
\begin{aligned}
q= & \frac{Q}{W}=\frac{i_{2}-i_{1}}{x_{2}-x_{1}}+\left(\frac{D}{W}-1\right) c_{D}\left(t_{e}-t_{i}\right)-t_{i} \\
& +\frac{Q_{t}}{W}+r_{0} \ldots \ldots \ldots \ldots \ldots \ldots \ldots \ldots \ldots \ldots \ldots \ldots \ldots \ldots \ldots \ldots \ldots \ldots \ldots
\end{aligned}
$$


$q, l$ 蒸発水量 $1 \mathrm{~kg}$ 当りの熱消費量および空気消費 量であり, 乾燥前後の空気状態变化の方向 $i_{2}-i_{1} / x_{2}-x_{1}$ は (96) 式から求められる.よって線図上で乾燥機入口 状態点から $i_{2}-i_{1} / x_{2}-x_{1}$ 線を周辺尺度を用いて引けば， この線上に乾燥機出口の空気状態がある.

次にこのような乾燥機内の空気状態変化を以上の上う な総括的な見方をしないで，別の方向から線図上に解析 すると第 24 図下に示すようになる。

まず湿り空気 1 が空気加熱器に入り, 絕対湿度一定の まま加熱されるから $x_{1}$ 線上を変化し, 状熊 3 となって 乾燥機内に送入される. 一方乾燥物は $t_{i}{ }^{\circ} \mathrm{C} て ゙$ 乾燥機に 供給されるから, 乾燥機大口に和ける乾燥物表面の湿り 空気は乾燥物温度で飽和していると考えると, 線図上で は $t=t_{i}$ 線と飽和線との交点 $I$ であらわされる. 同様に 乾燥機出口に打子る乾燥物表面空気は出口温度 $t_{e}$ 線と 飽和線との交点 $E$ で与えられる.

一般に $t_{w}{ }^{\circ} \mathrm{C}$ の乾燥物表面を流れる空気の状態変化は $d i / d x=t_{w}-r_{0}$ の方向線に沿って行われるが, 乾燥物温 度が $t_{i}$ から $t_{e}{ }^{\circ} \mathrm{C}$ まで連続的に変化するために, これ に応じて乾燥空気の状態変化の方向が刻々と变化してい く.このため乾燥空気の状態変化は線図上では複雑な軌 跡をかき，これを追跡することは実際上極めて困難であ る・したがって乾燥窒内での空気状態変化を次のように 仮定する。

（a）空気加熱器を出て乾燥機に大る乾燥空気 3 は絶 対湿度一定のま乾燥物を $t_{i}$ から $t_{e}^{\circ} \mathrm{C}$ まで上昇させ, さらに機外への損失熱量 $Q_{l}$ に相当する熱量だけ冷却さ れて $3^{\prime}$ の状態となる.

(b) $3^{\prime}$ 状態の乾燥空気は乾燥物の終末温度 $t_{e}^{\circ} \mathrm{C}$ の 水分蒸発によって加湿され, $\Delta i / \Delta x=t_{e}-r_{0}$ 線に沿って 状態変化する。

そうすればこの場合の熱量関係式は次のようになる。

$$
\begin{aligned}
& i_{3}+x_{3} r_{0}=i_{1}+x_{1} r_{0}+\frac{Q}{G_{a}}, x_{3}=x_{1} \\
& i_{3}-i_{3^{\prime}}=\frac{1}{G_{a}}\left\{(D-W) c_{D}\left(t_{e}-t_{i}\right)-W t_{i}+Q_{l}\right\}
\end{aligned}
$$

したがって乾燥空気は $3^{\prime}$ 点を通る $\Delta i / \Delta x=t_{e}-r_{0}$ 線 すなわち $E$ 点を通る冷却極限温度 $t^{\prime}$ 線に平行な直線上 を变化する。しかる乾燥機出口に打いては乾燥物と湿り 空気とは熱的平衡を保持しているから， $E$ 点を通る定常 温度 $\tau$ 線上に空気出口状態がなければならない。したが ってこの両線の交点 2 が乾燥機出口の空気状態を示すこ と沉なる。

いま乾燥問題の線図解の一例として $D=1000 \mathrm{~kg} / \mathrm{h} の$
乾燥物が $5{ }^{\circ} \mathrm{C}$ で乾燥機化大り, $50 \mathrm{~kg} / \mathrm{h}$ の水分が除去 されて, 温度 $29.5^{\circ} \mathrm{C} て ゙$ 乾燥機から出ていく場合, 乾燥 機内の空気状態变化を $i 一 x$ 線図上にかき, 必要空気量, 必要熱量, 排気損失熱量について検討する・ただしこの 境合空気加熱器に供給する空気状態は $t_{1}=14^{\circ} \mathrm{C}, \varphi_{1}=60$ $\%$ であり, 出口空気 $\varphi_{2}=48 \%$ であるとし, 乾燥物比 熱 $c_{D}=0.3 \mathrm{kcal} / \mathrm{kg}^{\circ} \mathrm{C}$ とする.

1 ) 乾燥過程の線図表示

第 25 四は乾燥機内の空気状態変化を示したものであ り, 乾燥各過程の空気状態について考元ると次の上うに なる。

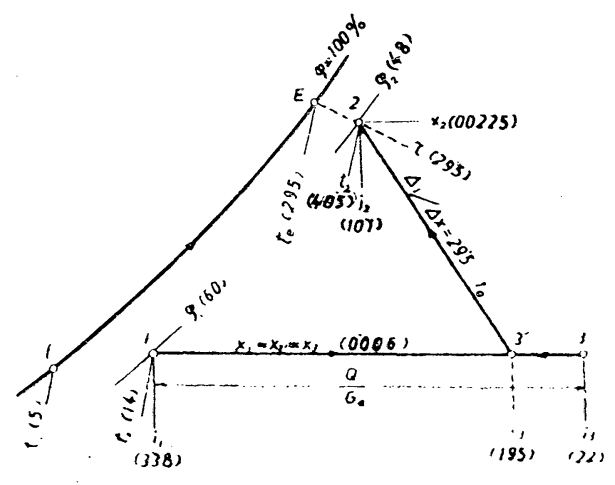

（第 25 図）

\section{（a）乾燥機入口空気状態}

この状態は $t_{1}=14^{\circ} \mathrm{C}$ 線と $\varphi_{1}=60 \%$ 線との交点 1 に よって卖えられる. この点は $x_{1}=0.006 \mathrm{~kg} / \mathrm{kg}$ 乾き空気，

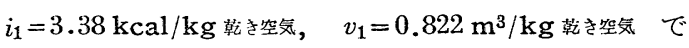
ある・空気加熱器内では $x_{1}=$ 一定のままで加熱され る.

\section{（b）乾燥機出口空気状態}

乾燥物表面の飽和湿り空気状態は大口に特いては $t_{i}=$ $5^{\circ} \mathrm{C}$ 線と飽和線との交点 $I$, 出口では $t_{e}=29.5^{\circ} \mathrm{C}$ 線と 飽和線との交点 $E$ で支えられる・したがって乾燥機出 口に打ける空気状態は $E$ 点を通る定常温度 $\tau$ (乱流) 線 と $\varphi_{2}=48 \%$ 線との交点 2 であらわされる.

しかしてこの点の状態は $x_{2}=0.0225 \mathrm{~kg} / \mathrm{kg}$ 乾き空気， $i_{2}=10.1 \mathrm{kcal} / \mathrm{kg}$ 勒き空気, $t_{2}=40.5^{\circ} \mathrm{C}$ である.

\section{（c）空気加熱器出口状態}

前述のように乾燥室内での空気状態変化を二分割し, まず乾燥物を加熱し, 次に $t_{e}{ }^{\circ} \mathrm{C}$ の一定温度の水による 加湿冷却と考光れば，この変化は 2 点を通る $\Delta i / \Delta x=t_{e}$ $-r_{0}$ 線すなわち $t^{\prime}=t_{e}{ }^{\circ} \mathrm{C}$ 線に平行な直線上に起る. し たがって $x_{1}=0.006 \mathrm{~kg} / \mathrm{kg}$ 暲き空气 線と $\Delta i / \Delta x=t_{e}-$ $r_{0}=567.6 \mathrm{kcal} / \mathrm{kg}$ 線との交点 $3^{\prime}$ を求め, (98) 式を 
用いて $i_{3}$ を算出して $x_{1}$ 線上に状態点 3 を求めれば， この点は空気加熱器出口状態を与兄る。また别行真熱量 $Q$ がわかれば (97) 式から状態3を決めることができ る.

しかして $i_{3}=22.15 \mathrm{kcal} / \mathrm{kg}$ 勘き等， $i_{3^{\prime}}=19.5 \mathrm{kcal} /$ kg 畭さ空勿である。

2) 必要空気量

(91) 式加占

$$
G_{a}=\frac{W}{x_{2}-x_{1}}=\frac{50}{0.0225-0.006}=3030 \mathrm{~kg} / \mathrm{h}
$$

3 ) 必要熱量

(96) 式から損知熱量 $Q_{l}$ がないとすれば

$$
\begin{aligned}
\frac{Q}{W} & =\frac{i_{2}-i_{1}}{x_{2}-x_{1}}+\left\{\left(\frac{D}{W}-1\right) c_{D}\left(t_{e}-t_{i}\right)-t_{i}\right\}+r_{0} \\
& =\frac{10.1-3.38}{0.0225-0.006}+\left\{\left(\frac{1000}{50}-1\right) 0.3(29.5\right. \\
& -5)-5\}+597.1 \\
& =407+134.7+597.1=1138.8 \mathrm{kcal} / \mathrm{kg}
\end{aligned}
$$

したがって必要熱量 $Q$ は

$$
Q=1138.8 \times 50 \doteqdot 57000 \mathrm{kcal} / \mathrm{h}
$$

この必要熱量 $Q$ の中には損失熱量 $Q_{l}$ が含まれてい ないから，実際の所要加熱量はこの值を机算したすので ある・ $i_{2}-i_{1} / x_{2}-x_{1}$ の值は上述のように計算によって求 める代りに，状態点 $1 ， 2$ を結占線分の平行線を極 0 か ら引いて周辺尺度の值を読みとってる求めることができ る.

\section{4) 排気損失熱量}

排気損失熱量 $Q_{2}$ を排気が持ち出す全熱量とすれば

$$
Q_{2}=G_{a}\left(i_{2}+x_{2} r_{0}\right)
$$$$
=3030 \times(10.1+597.1 \times 0.0225)=71310 \mathrm{kcal} / \mathrm{h}
$$

しかして $\left(i_{2}+x_{2} r_{0}\right)$ は $i 一 x$ 線図の 2 点のエンタルピ 1 の詤みからもすぐ求まる.

本例の乾燥機について熱精算を行えば

乾燥機比持ち込を空気熱量

$$
Q_{1}=G_{a}\left(i_{1}+x_{1} r_{0}\right)
$$

$$
=3030(3.38+597.1 \times 0.006)=21097 \mathrm{kcal} / \mathrm{h}
$$

所要加熱量 $Q=56940 \mathrm{kcal} / \mathrm{h}$

乾燥物の温度上笔に要する熱量は

$$
\begin{aligned}
& \left\{\left(\frac{D}{\mathscr{W}}-1\right) c_{D}\left(t_{e}-t_{i}\right)-t_{i}\right\} W \\
& \quad=134.7 \times 50=6735 \mathrm{kcal} / \mathrm{h}
\end{aligned}
$$

、となるが,一方

$$
\left(Q_{1}+Q\right)-Q_{2}=\left\{\left(\frac{D}{W}-1\right) c_{D}\left(t_{e}-t_{i}\right)-t_{i}\right\} W
$$

でなけ礼ばならないが

$(21097+56940)-71310=6727 \mathrm{kcal} / \mathrm{h}$
となり，上述の綕果と一致する。

なお，この例題は低温乾燥の場合であるが, 高温乾燥 で惊温压の $i 一 x$ 線図を利㕆すればよい。

\section{3. 连続乾燥の諸方式}

乾燥機の熱経済および乾燥能率を增すために次の中間 加熱, 空気循環および排気熱の回収利用などの方法があ るが，いまこれらの場合について $i 一 x$ 線図上で状態变 化を図示して吟沬する。

\section{(i) 中間加熱法}

一般に畭爆物表面からの空気中への水分蒸発怯物体表 面の湿り空気の絕対湿度と気流の絕対湿度との差飞比例 し，また飽和湿り空気の縃対湿度 $x_{s}$ は温度 $t$ の上昇に 対して急激兽大寸る性質をるっているが，乾燥物の温 度が高いほど蒸発力は大きく，蒸発速度は増加する。し たがって乾燥能率すなわち所定の乾燥条件下に括ける算 位時間当りの乾燥物処理量を增すためにはてできるだけ 高温の乾橾空気を周いて乾燥物温度を高くしなければな らない.しかし乾煤物の物理的, 化学的性質から乾燥に 対するいろいるな条件によって制約をうける。例えば韯 維裴品に対しては $100^{\circ} \mathrm{C}$ 以上に高温に加熱することは 適当でなく，木材やせっけんなどに対してはあまり急速 な乾燥屾亀裂を起す原因となり，さらに一般薬品類にい たっては複雑な乾燥条件が決められている。したがって 加熱された乾燥用空気の最高温度がある温度以下に制限 されているような場合に，乾燥能率を増加するためには 乾燥室の途中から抽気し, 再加熱して次の乾噮機中に送 り込む中間加熱方式がしばしば採用される。
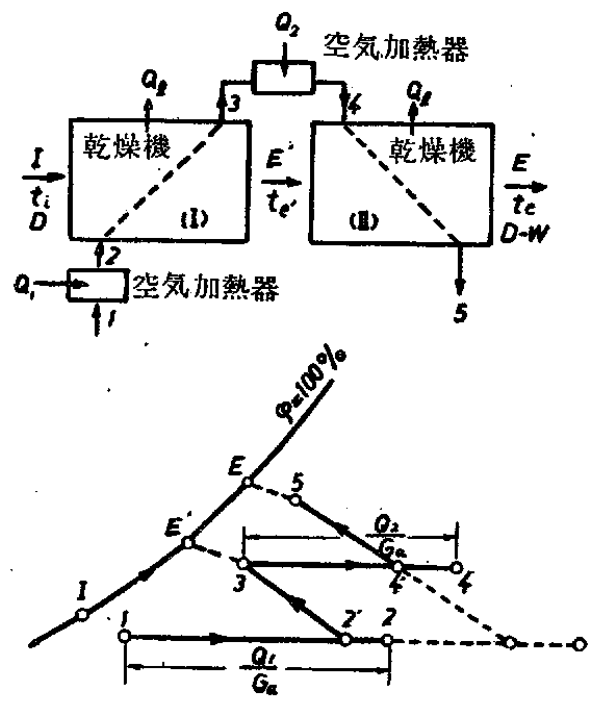

(第 26 次) 
第 26 四はこの方式の概略図と乾燥過程を線図上に示 す説明図である。

すなわち状態 1 の空気が加熱器により状態 2 まで熱 されて乾燥機内に送入される。ここで前の場合と同じよ 5 亿乾燥物温度上昇 $\left(t_{e^{\prime}}-t_{i}\right)$ 亿要する熱量抢よび乾燥機 （I）からの損失熱量のために $x_{1}$ 一定のまま冷却され， $2^{\prime}$ の状態から $\Delta i / \Delta x=t_{e^{\prime}}-r_{0}$ の方向線に沿って乾燥工 程が行われると考える・交乾燥機 (I) 出口の乾燥物 温度は $t_{e^{\prime}}{ }^{\circ} \mathrm{C}$ であるから, 乾燥機 (I) 出口の空気状態 は $t=t_{e^{\prime}}$ 線と飽和線との交点 $E^{\prime}$ を通る定常温度 $\tau$ 線 と $2^{\prime}$ を通る $\Delta i / \Delta x$ 方向線との交点 3 として求められ る.この 3 の状態の乾燥空気は中間空気加熱器に入って $t_{4}{ }^{\circ} \mathrm{C}$ まで加熱されて乾燥機（II）に送入され，乾燥機 (I) 内の乾燥過程と同じ状態变化を繰り返して, 状態 5 となって乾燥機から排出される.

図中の点線は同一の乾燥効果を得るための中間加熱を 行わない場合の状態変化を線図上に示したものでこれ と実線を比較すれば中間加熱の有用性が明白になる。

\section{(2) 空気循環法}

乾燥機排気が持ち出す全熱量は比較的大きく,この排 気熱の一部を回収して必要加熱量を軽減し，乾燥機の熱 経済を図ろらとする方式である。

第 27 図はこの方式の概略とその乾燥過程を線図上に

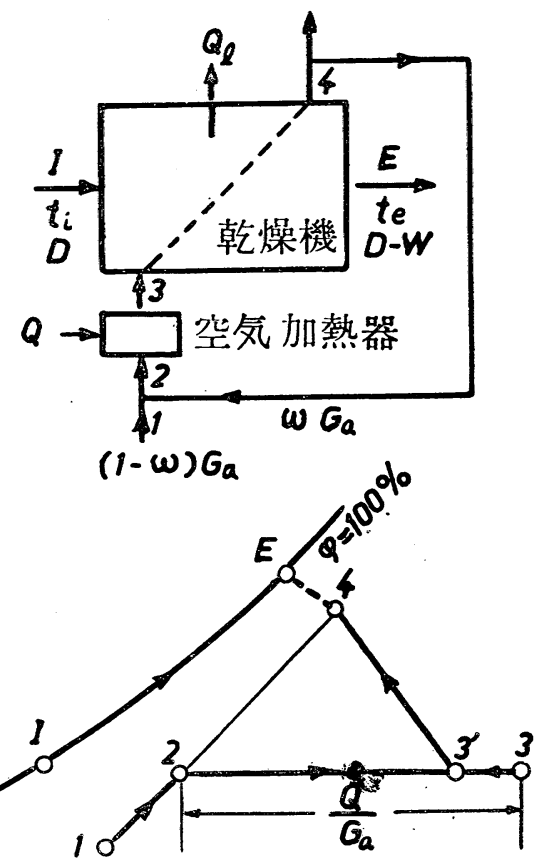

（第 27 図）
かいたものであり，排気の一部と供給空気 1 とを混合し て状態 2 の空気を加熱機に送る方式である. 排気の返還 率をいとすれば図に打いて

$\overline{12}: \overline{24}=\omega:(1-\omega)$

であり, 混合後の空気加熱機送入前の空気状態は

$$
\begin{aligned}
& x_{2}=(1-\omega) x_{1}+\omega x_{4} \\
& t_{2}=(1-\omega) t_{1}+\omega t_{4} \\
& i_{2}=(1-\omega) i_{1}+\omega i_{4}
\end{aligned}
$$

である。この場合空気循環による回収熱量は

$$
\omega G_{a}\left(i_{4}+x_{4} r_{0}\right)
$$

であり，乾燥機の乾燥効率 $\eta$ を

$$
\eta=\frac{\text { 水分蒸発に用いられた熱量 }}{\text { 乾燥機の鹪熱量 }}
$$

と定義すると, 水分蒸発に用いられた熱量は湿り空気中 の潜熱量の変化㳊等しいと近似的に考兄られるから

$$
\eta=\frac{G_{a}\left(x_{4}-x_{2}\right) r_{0}}{Q}=\frac{x_{4}-x_{2}}{i_{3}-i_{2}} r_{0}
$$

によって示される。

再循環しない場合の効率 $\eta_{0}$ は（第 24: 図参照）

$$
\eta_{0}=\frac{G_{a}\left(x_{2}-x_{1}\right) r_{0}}{Q}=\frac{x_{2}-x_{1}}{i_{3}-i_{1}} r_{0}
$$

(3) 排気熱利用法

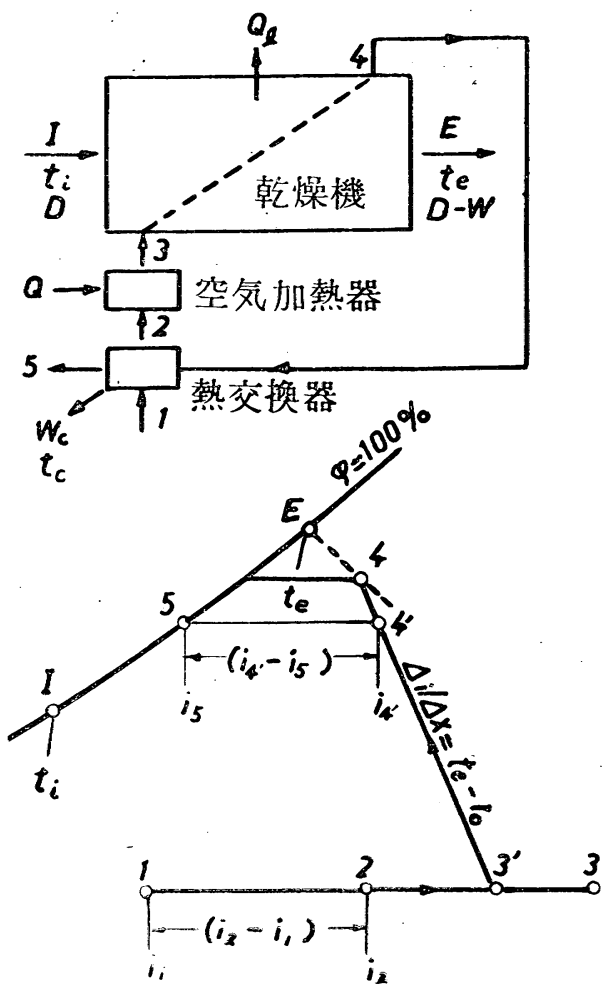

(第 28 汹) 
第 28 図に示すように排熱を利用するため，排気を熱

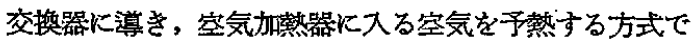
ある.すなわち状態 1 の空気は排気利厉熱交換器淿より 加熱され状態 2 となり，さらに空気分熱器によって状態 3 まで加熱されて乾㷄機に送入される。状態 4 で機外に 排出され，熱交換器汇導かれる。ここで減湿冷却される が，そのときの㠜縮水量を $W \mathrm{ckg} / \mathrm{h}$, 凝縮水温を $t_{a}{ }^{\circ} \mathrm{C}$ とすれぱ，この乾燥機に対して次の関係式が成り立つ.

$$
\begin{aligned}
& G_{a}\left(i_{1}+x_{1} r_{0}\right)+(D-W) c D t_{i}+W t_{i}+Q \\
& =G_{a}\left(i_{5}+x_{5} r_{0}\right)+(D-W) c_{D} t_{e}+W t_{c}+Q_{l}
\end{aligned}
$$

熱交換器では

$$
i_{2}-i_{1}=\left(i_{4}-i_{5}\right)+\left(x_{4}-x_{5}\right)\left(r_{0}-t_{6}\right)
$$

の熱量が回収される。

いま図に扎いて凝縮点 5 より平行線を引き， の交点を 4 とすると

$$
\begin{aligned}
& \frac{i_{4^{\prime}}-i_{4}}{x_{4^{\prime}}-x_{4}}=t_{e}-r_{0} \\
\therefore \quad & i_{4^{\prime}}=i_{4}+\left(x_{4}+x_{4^{\prime}}\right)\left(r_{0}-t_{e}\right)
\end{aligned}
$$

しかして $x_{4^{\prime}}=x_{5}$ であるから

$$
i_{2}-i_{1}=i_{4^{\prime}}-i_{5}
$$

したがって $\left(i_{4^{\prime}}-i_{5}\right)$ の長さに等しく1点からの $x_{1}$ 一 定線上に 2 点を定めれば，この点が熱交換器通過後の空 気状態を示す。

一方水分の収支については

$$
W=G_{a}\left(x_{4}-x_{1}\right)+W_{0}
$$

であるからこれらの関係式から単位蒸発水量当りの熱 消費量 $q$ を求めると

$$
\begin{aligned}
q= & \frac{Q}{W}=\left(1-\frac{W_{c}}{W}\right) \frac{i_{5}-i_{1}}{x_{5}-x_{1}} \\
& +\left(\frac{D}{W}-1\right) c_{D}\left(t_{e}-t_{i}\right)-t_{i} \\
& +\frac{W}{W} t_{c}+\frac{Q_{l}}{W}+\left(1-\frac{W_{i}}{W}\right) r_{0}
\end{aligned}
$$

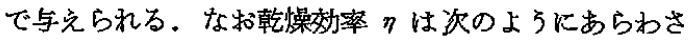
れる。

$$
\eta=\frac{x_{4}-x_{1}}{i_{2}-i_{3}} r_{0}
$$

\section{4. 乾燥室による乾燥方式}

この方式は乾燥物を乾燥室に供給して，連続的でなく 断続的に乾燥を行う方法であり, 乾㷥物は所定の乾燥が
得られるまでは乾燥窒内にとどめ，乾煤空気のみは連続 的送大するむのである。

第 29 四はこの型の最も基本的な乾煤方式の説朋図で

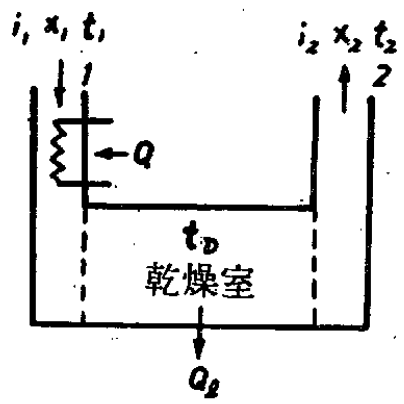

（第 29 図）

ありこの㙏合の熱収支は次式によって与えられる。

$$
G_{a} i_{1}+Q+W t_{D}=G_{a} i_{2}+Q_{l}+W r_{0}
$$

また蒸発水量 $W \mathrm{~kg} / \mathrm{h}$ は

$$
\begin{aligned}
& W=G_{a}\left(x_{2}-x_{1}\right) \\
\therefore \quad & q=\frac{Q}{\mathscr{W}}=\frac{i_{2}-i_{1}}{x_{2}-x_{1}}-t_{D}+\frac{O_{l}}{W}+r_{0}
\end{aligned}
$$

この方式に执いても，連続乾燥式と同じょうに第 30 四に示すような空気循環法を用いることがある。

空気の循環によって乾燥空気の温度は上昇しますま す乾燥物表面からの水分蒸発を盛んにするが，空気温度

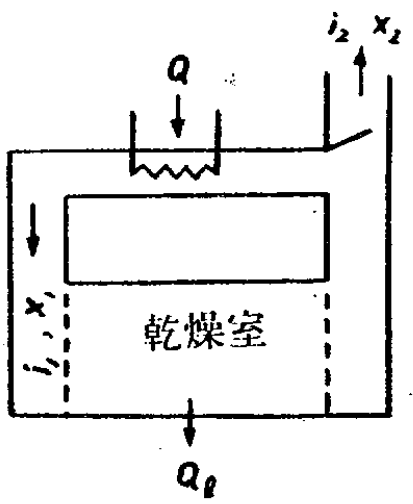

（第 30 図）

が $100^{\circ} \mathrm{C}$ になると空気の奇圧は 0 となり，乾燥窒内に は水蒸気のみが循環する。なおこれ以上の水分吸収を行 ラためには蒸気は過熱状態でなければならないので，比 較的高温乾燥に耐える乾燥物以外には使用できない。

\section{5. 蛈㥺ガスによる乾燥}

水蒸気を除いた燃焼ガスのエンタルピ $i_{f}$ が乾燥空気 
のエンタルピ $i_{a}$ と大差なく，if山i $i_{a}$ と考えられるとき には、然焼ガスを直接利用する乾燥問題にす・湿り宾気 i一 $x$ 線図を用いることがでさる。

よって $(1+x) \mathbf{k g}$ の然焼ガスのエンタルピ iF $\mathrm{kcal} /$

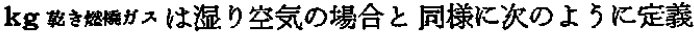
される。

$$
i_{k^{\prime}}=i_{f}+x i_{w}
$$

しかして燃焼ガスによる乾燥過程では熱量の供給がな いときには $\Delta i / \Delta x=t_{D}-r_{0}\left(t_{D}\right.$ は乾燥物温度) の方向に 状態変化し；線図上に乾嬠状態変化を解析でることは これまで述べた乾燥空気の場合同様である。

な和乾燥物から $1 \mathrm{~kg}$ の水分を吸取するのに必要な乾 き燃焼ガスの量は $1 / x_{2}-x_{1} \mathrm{~kg} / \mathrm{kg}$ であるので， $1 \mathrm{~kg}$ の水分蒸発に消費される然料を $\boldsymbol{B} \mathbf{~ k g}$ とすると

$$
B=\frac{b}{x_{2}-x_{1}}
$$

ここに $b$ は $1 \mathrm{~kg}$ の乾き燃焼ガスを発生するのに必 要な然料重量である.

約 $100^{\circ} \mathrm{C}$ 以上に熱してはならない乾懆物では然焼ガ
スの温度を下け゚るために，乾操機に入る前に空気と混合 して送大する。

この混合ガス $M$ の状態は混合比 $n$ によって次のよ うになる。

$$
\begin{aligned}
& x_{M}=\frac{x_{F}+n x}{1+n}, \quad i_{M}=\frac{i_{F}+n i}{1+n} \\
& n=\frac{G_{B}}{G_{F}}=\frac{x_{H}-x_{M}}{x_{M}-x} \ldots \ldots \ldots \ldots
\end{aligned}
$$

この場合乾燥物から $1 \mathbf{k g}$ の水分を取り除くための混 合ガス量は

$$
\frac{1}{\left(x_{M 2}-x_{M 1}\right)(1+n)}
$$

であり，所要必要然料 $B \mathrm{~kg} / \mathrm{kg}$ は

$$
B=\frac{b}{\left(x_{M_{2}}-x_{M_{1}}\right)(1+n)}
$$

である.ここで $\left(x_{M Z}-x_{M 1}\right)$ と $n$ との間には相関があ ク, $n$ が増大すると $\left(x_{M 2}-x_{M 1}\right)$ は減少する。しかし $\left(x_{M_{2}}-x_{M_{1}}\right)(1+n)$ の值は $n$ の増大につれて増し, $B$ は減少して空気の濯合率が高くなるほど然料消費率は下 がる。

\section{海外餈料研究部会員募 集}

海外交献の抄録紹介は少なからず見受けられるが、理論的な又実際的にまとまった研究の䧽訳紹介は非常

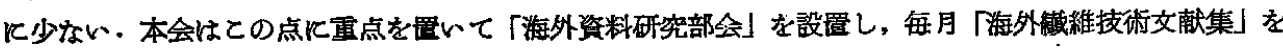

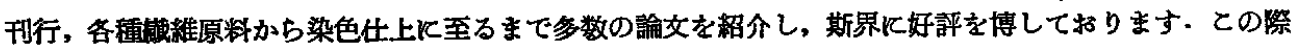
御入会を㕲馬めします。

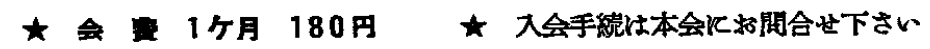

56 是 $(1956-6)$ 内目次

记繊維塊を通る宾気流(第2 部)

Shirley Inst, 1955-10.

々長瀻維織物の無光讯程度の測定 $(1,2$ 報)

J. Text. Inst., 1955-6,12.

々人造及び合成珷維紡績系の弓張特性

Text. Res. J., 1955-10.

乞腤物組織と物理的特性の関係（第 5 報）

Text. Res. J., 1956-2.
々重ねた織物の保温性

Text. Res. J., 1955-9.

乞紡織仕上に用いられる重合性粼酸塩類

Text. Praxis, 1955-6.

方永持らする伝動ペルトの選び方

Text. World, 1954-2. 